\title{
On the Cover
}

Portions of the following are based on an interview with the artist on July 14, 2014.

"Caught in the act" is how psychologist and sculptor Julian Meltzoff describes his body of work. Visiting his home and studio, the hundreds of clay and bronze figures give evidence that indeed he is interested in creating figurative images of people engaged in some activity. His interest in the perception of movement in pictures dates back to a series of research studies he conducted with colleagues in the 1950s on the relationship of Rorschach human movement $(\mathrm{M})$ responses to motor, cognitive, and affective inhibition. Known for his influential Day Treatment Center, widely used Research in Psychotherapy and his popular Critical Thinking About Research, Meltzoff had to decide what to do with his life when he retired at age 77 from a long career as a clinical and academic psychologist.

One day Meltzoff accompanied his wife Antonia, a psychologist who likes to paint, to an art supply store so she could pick up some materials. He brought home some clay that hardens when baked in an ordinary kitchen oven. Now that he was retired, he had ample free time to pursue any interests, and the idea of clay modeling looked appealing. He had admired sculptures and paintings in the many museums he had visited in his extensive travels around the world, but had never had any formal training in art. Julian's older brother, Stanley, was a well-known painter and art historian. The idea of painting was unappealing to Julian because the bedroom he shared with Stanley when they were growing up also served as his brother's studio and always smelled of turpentine. Art had been his brother's exclusive domain, so when he became a sculptor, Julian was hesitant to tell Stanley about it. When Stanley saw the works, he was completely surprised, yet encouraging.

Meltzoff described what happened when he started to make clay images: "I accidentally discovered a latent talent for sculpture that emerged fully formed as did Athena from the brow of Zeus. When I received positive reinforcement for my initial efforts at clay modeling I proceeded hungrily to produce more and more and still continue to sculpt at age 93." Instead of using live models, he relies upon a lifetime of visual images stored in his memory of people engaged in all sorts of real-life activities. He also draws upon his own images of things he has heard, read, or imagined.

Born in 1921, Meltzoff grew up in the Bronx during the Great Depression and graduated from college in 1941, the year of the U.S. entry into World War II. Initially in the field artillery, he was reassigned to a specialized training program that was allegedly designed to prepare him to become a personnel officer. Sent to the University of Pitts- burgh for about six months, he received the equivalent of a master's degree in personnel psychology. By then the complexion of the war had changed and there was an urgent need to prepare troops for the coming European invasion. He was assigned to serve with a psychiatrist in an infantry division. Together they were responsible for dealing with the large number of soldiers suffering from what was then called "battle fatigue" or "combat exhaustion" as their unit fought its way from France through Holland and Germany. After this experience, he knew that clinical psychology would be his life's work. When he came home, he entered the initial VA training program and received his $\mathrm{PhD}$ from the University of Pennsylvania in 1950.

The artist said he feels differently about his art compared with his work as a psychologist, because he does not have to sculpt to make a living but does it only because he wants to. The "little people" that he makes are displayed throughout his home. Some, including the sculpture on the cover, are cast into bronze, some have been exhibited, and some are in private collections. Once they exist, he finds it hard to part with them. His works fall into 23 categories, including beach scenes, city street scenes, music themes, dance scenes, Greek mythology, human relations, mothers and children, circus scenes, academic scenes, and war and military scenes, to mention a few. Most are stop-action or freeze-frame images of people in arrested motion.

Meltzoff commented, "The cover sculpture, Body in Motion, of a woman doing sit-ups, takes it a step beyond a static stop-action portrayal. By presenting a linked series of successive figures in progression from a supine, to an upright, to a forward position, the intent is clearly to lead the viewer to infer motion. To create a true illusion of motion rather than just a strong impression of it, one would have to present views of a progressively changing figure, such as the woman doing sit-ups, at the flicker fusion rate of 24 images per second. This is what Muybridge did with his zoopraxiscope, the precursor to motion pictures. Meltzoff's interest in the issue of movement is further explored in his article, "Errors in the Making and Perception of Art Images of Human Gait: Psychological Explanations," in the journal Psychology of Aesthetics, Creativity, and the Arts (2014, Vol. 83, pp. 321-329).

The artist began reading the American Psychologist in 1946 when it was a fledgling journal and he was a graduate student. "Now," he said, "some 69 years later, it pleases me to have one of my artworks on the cover of this journal."

Sandra M. Fowler Art Co-Editor 